\title{
Legal basis for the participation of an expert in the proceedings of the Russian Federation and the United States of America
}

\author{
Elena Anatolievna Logvinets ${ }^{1}$, Natalia Petrovna Katorgina, Natalia Yurievna Sudnikova, \\ Sergey Nikolaevich Mamin, and Irina Nikolaevna Kislitsina \\ Belgorod State University, Department of Forensic Science and Criminalistics, Law Institute, \\ Belgorod, Russia
}

\begin{abstract}
The purpose of this research is to consider the legal status of an expert in the legal proceedings of the Russian Federation and the United States. In the paper used were such research methods as analysis, synthesis, formal legal and comparative legal. The methods of analysis and synthesis were used to clarify the legal status of an expert in the Russian Federation and the United States. The use of formal legal and comparative legal methods made it possible to conduct a comprehensive comparative study of procedural legislation. The authors applied an integrated approach to the study of the role and essence of competent persons in the two countries' proceedings. The comparative legal analysis of the rules of proceedings of the Russian Federation and the United States resulted in an assessment of the legislative regulation of the institute of specific expertise in legal proceedings. The given methodological tools made it possible to comprehensively generalise and systematise theoretical postulates, develop their own opinion on issues of the expert participation in the proceedings of the Russian Federation and the United States discussed in the scientific literature. The novelty of the research lies in the fact that it made it possible to assess further prospects for engaging competent persons in Russian legal proceedings. The results obtained during the work can be used for further research in the field of application of special knowledge in the legal proceedings of the Russian Federation and the United States.
\end{abstract}

Keywords: expert, competent person, specific expertise, legal proceedings

\section{Introduction}

The importance of narrow-focused knowledge has recently been increasing significantly, which is due to the promotion of means and methods that allow committing "conventional" offences in new ways. Thus, often the activities of law breakers are aimed at committing illegal socially dangerous acts with the Internet (for example, inducement to commit suicide; fraud; illegal drug trafficking). Objective reality necessitates to attract qualified specialists versed in applied fields of knowledge, which, in turn, requires improved

${ }^{1}$ Corresponding author: logvinets@bsu.edu.ru

legislation. Knowledge of the legal experience of foreign countries, including the United States of America (hereinafter the USA), contributes to the search for new forms of participation of competent persons in Russian legal proceedings. 
Specific expertise is an important procedural institute that establishes the grounds for the participation of competent persons in legal proceedings, as well as the possibility of using their knowledge with the most recent scientific and technical methods and means of committing illegal acts in mind. The involvement of an expert in legal proceedings is commonly discussed in foreign scientific literature. At the same time, most authors focus on promoting the use of specific expertise in the consideration of the case as a guarantee of improving its quality and reducing the duration $[1 ; 2$, p. 14].

\section{Methods}

The paper used research methods in respect of the stated topic. The methods of analysis and synthesis were used to clarify the legal status of an expert in the Russian Federation and the United States. The use of formal legal and comparative legal methods made it possible to conduct a comprehensive comparative research into procedural law. The given methodological toolkit made it possible to comprehensively analyse, generalise and systematise theoretical postulates, develop their own opinion on issues of the expert engagement in the proceedings of the Russian Federation and the United States discussed in the scientific literature.

\section{Results and discussion}

There are both common and distinctive features in understanding the role and essence of a competent person in legal proceedings between the procedural legislation of the Russian Federation and the United States.

Based on the analysis of the procedural law of the Russian Federation, an expert and a specialist are the key subjects of the use of specific expertise. Understanding of the essence of an expert and a specialist, irrespective of the type of Russian legal proceedings, remains practically the same. So, an expert is usually understood as a person with specific expertise in science, technology, art or craft, appointed to carry out an examination and give an opinion; a specialist is a person with specific expertise and involved in the detection, consolidation and seizure of evidence, the use of technical aids, as well as to clarify issues within his/her professional competence. Thus, an expert is endowed with a research function, and the activities of a specialist are aimed at providing advice and technical assistance.

US legal proceedings, the bearer of specific expertise is an expert, whose procedural status in the legislation is designated as a witness [3, 4]. An expert is a person with scientific, technical or other specific expertise, skills, experience, training or education and can give evidence on the issues raised [5]. US law provides an expert with a research, technical, and advisory function. In this case, the expert can be brought in by a court ("the court-appointed expert", "the court's expert") and also the opposing parties ("the testifying expert", "the non-testifying expert", "the consulting expert") [6, pp. 6-7].

Understanding the purpose of an expert in legal proceedings in the Russian Federation is similar to understanding the purpose of an expert in legal proceedings in the United States. However, if in the legal proceedings of the Russian Federation an expert implements only a research function, and the performance of a technical 
and advisory function is the responsibility of a specialist, then in the US legal proceedings the context is different; an expert is involved in using specific expertise in various activities in order to obtain technical and advisory assistance by the court, as well as to conduct research.

The main document governing the activities of an expert in US legal proceedings is the Federal Evidence Rules, dated December 1, 2017, which consists of 11 articles and 1103 rules. The involvement of an expert is assigned Article VII. Opinions and expert testimony Federal rules of evidence. December 1, 2017, which includes 6 rules. Those rules contain the rules governing the activities of an expert when giving evidence and the specifics of the appointment of an expert examination by the court.

So, according to Rule 706 [5], the court can involve a competent person in the proceedings only with the voluntary consent to participate as an expert. The court, at its own discretion or at the request of either of the parties, may issue a reasoned order on the impossibility of the declared expert to participate in the proceedings. In the procedural law of the Russian Federation, there is a similar procedure, which is called "challenge of expert" [8]. The court or the parties to the proceedings may challenge an expert if there are doubts about his/her neutrality.

In US litigation, a document drawn up by an expert as a result of an examination is called a "message", "report" or "report" [6, p. 99; 9, p. 239]. However, the expert in the court normally presents his/her report orally. At the same time, the psychological aspect is essential when presenting a report $[6 ; 10, p .1]$. An expert should explain in plain language to the court and the opposing parties the facts, phenomena, events that have become the subject of his/her examination. Tactical assistance to an expert in preparing his/her speech and determining the line of conduct is often provided by a lawyer $[6,7 ; 9$, pp. 10, 20].

In necessary cases, the court has the right to request a written report from an expert, which may contain both a full-fledged expert examination and a statement of his/her opinion without conducting an examination. In essence, providing a competent person with their judgments is a written consultation of an expert on a controversial issue. The structure of the expert's report has not been determined by the Federal Rules of Evidence, December 1, 2017.

In accordance with the legal provisions of the Russian Federation, an expert, based on the results of the examination, draws up a written conclusion, the structure of which is enshrined in law. A written consultation on the issues raised without conducting an examination in Russian law is carried out by a specialist who gives explanations, expresses his/her opinion on the problematic issue. A written consultation of a competent person is drawn up by a specialist's opinion, which, along with an expert's opinion, is a source of evidence [11].

The court, the parties to the US legal proceedings assess the competence of an expert by having a certificate or licence for this activity (for example, an expert in medicine has the right to testify only in a specialised field and after receiving the appropriate certificate [4, 12-14]. If an expert does not have this document, then he/she can be involved in legal proceedings only as an assistant or technical consultant ("the consulting expert", "the lay witness") [6, p. 3; 15, p. 4]. In the legal proceedings of the Russian Federation, in addition to determining the competence of an expert, for example, compliance with the procedural arrangements for the appointment and production of an examination is subject to verification; the presence of all the necessary details in the expert's opinion specified in the law; 
authenticity and sufficiency of the investigated evidence; reliability and completeness of the opinion etc. The analytical and thinking activity of the court should consist in comprehending the information received and formulating an independent opinion on the basis of the evidence collected in the aggregate.

\section{Conclusion}

The study of the forms of participation of an expert in the proceedings of the Russian Federation and the United States made it possible to determine both common and distinctive features in understanding the role and essence of an expert, which made it possible to comprehend and understand further prospects for engaging competent persons to legal proceedings in order to establish the truth in the case, and, ultimately account, determined the feasibility of the subsequent in-depth study of the institute of specific expertise.

\section{References}

1. I. Kopp, Professor and director, SKL.Organization and history of the member laboratories, in 14-th Meeting Linkoping 2002, the European Network of Forensis Science Institutes (2002)

2. E. Radzevicius, The application of the special knowledge investigating criminal violations of the requirements of the work safety regulations: theory and practice in Lithuania, Summary of Doctoral Thesis. Sosial Sciences, Law (01 S) (Mykolas Romeris University, Vilnius, 2006)

3. S.L. Murray, Professional Safety, 3, 20-23 (2009)

4. The 2020 Florida Statutes, Accessed on: January 24, 2021. [Online]. Available: http://www.leg.state.fl.us/statutes/index.cfm?App_mode=Display_Statute\&Search_Stri $\mathrm{ng}=\& \mathrm{URL}=0400-0499 / 0458 /$ Sections $/ 0458.3175 . \mathrm{html}$

5. Federal rules of evidence. December 1 (2017), Accessed on: December 14, 2020.

[Online]. Available:

https://www.uscourts.gov/sites/default/files/evidence-rules-procedure-dec2017_0.pdf

6. J.G. Speight, The Scientist or Engineer as an Expert Witness (CRC Press, New York, 2009)

7. F.C. Smith, R.G. Bace, A Guide to Forensic Testimony: The Art and Practice of Presenting Testimony as an Expert Technical Witness (Pearson Education lnc., Boston, 2003)

8. Federal law No. 73-FZ dated May 31, 2001 (as amended on July 26, 2019) "State Forensic Expert Activities in the Russian Federation", "ConsultantPlus" computer-based legal reference system

9. Z. Telpner, Expert Witnessing in Forensic Accounting: Handbook for Lawyers and Accountants (CRC Press, 2002)

10. J.G. Speight, M.C. Calhoun, Legal Backgrounder, 23(37), 1-4 (2008) 11. The Criminal Procedure Code of the Russian Federation of 12/18/2001 No. 174-FZ (as amended on 12/08/2020), "ConsultantPlus" computer-based legal reference system 12. A. Baker, Forensic science international: Synergy, 1(1), 161-169 (2019), https://doi.org/10.1016/j.fsisyn.2019.09.007 
13. H. Melbourne, J. Smith, J. McFarland, M. Rogers, K. Wieland, D. De Wield, S. Lighthart, M. Quinn, A. Baxter, L. Cuarino, Forensic science international: Synergy, 1, 161-169 (2019), https://doi.org/10.1016/j.fsisyn.2019.08.001

14. Medical Expert Certificates: A Unique Requirement in Florida Courts, Accessed on: January 24, 2021. [Online]. Available:

https://www.expertinstitute.com/resources/insights/medical-expert-certificates-a-uniqu e-requirement-in-florida-courts/

15. B.A. Garner (ed.), Black’s Law Dictionary (Thomson Reuters, New York, 2009) 